\title{
Recurrence of peripheral T-cell lymphoma as granulomas in the lower limbs
}

\author{
Granulomas epitelióides cutâneos, como manifestação de recidiva de linfoma \\ de células T periférico
}

\author{
Ana Rita Travassos ${ }^{1}$ \\ João Raposo ${ }^{3}$ \\ Paulo Filipe ${ }^{2}$
}

\author{
João Borges-Costa ${ }^{2}$
}

Luís Soares Almeida²

\begin{abstract}
The presence of granulomas in the skin of T-cell lymphoma patients is a rare but well-known phenomenon. The authors present the case of a 44-year-old Caucasian male, with a previously treated peripheral T-cell lymphoma, with cutaneous infiltration and extensive dyschromia on his lower limbs. Skin biopsies revealed the presence of sarcoid granulomas associated with the recurrence of the lymphoma, confirmed by immunostaining and molecular analysis. Although a new scheme of chemotherapy was started, he died 18 months later. There are two different patterns of skin granulomas associated with lymphoma: granulomatous infiltrates admixed with neoplastic cells and cutaneous granulomas constituting a nonspecific manifestation of the underlying lymphoma, but presently there is no evidence supporting their relationship with lymphoma prognosis.
\end{abstract}

Keywords: Granuloma; Lymphoma, T-Cell, peripheral; Recurrence

Resumo: A presença de granulomas cutâneos associados a linfomas é um fenômeno raro, mas bem conhecido. Um homem, 44 anos de idade, com diagnóstico prévio de linfoma de células T periférico, foi enviado à nossa consulta por infiltração cutânea e extensa discromia nos membros inferiores. A biopsia cutânea revelou a presença de granulomas epitelioides associados à recidiva do linfoma, confirmada pela marcação imuno-histoquímica e estudo molecular. Apesar de iniciado novo esquema de quimioterapia, o doente faleceu 18 meses depois. Na literatura são descritos dois tipos de granulomas cutâneos na presença de linfomas: associados à infiltração cutânea pelo linfoma ou como uma manifestação não específica do linfoma. Contudo, atualmente não há evidência que suporte a sua relação com o prognóstico dos linfomas. Palavras-chave: Granuloma; Linfoma de células T periférico; Recidiva

\section{INTRODUCTION}

The presence of granulomas in the skin of T-cell lymphoma patients is a rare phenomenon, but it may be observed either in primary skin lymphomas or systemic lymphomas. ${ }^{1,2}$ These granulomas may precede, concur or develop after the diagnosis of lymphoma and dermatologists need therefore to be able to recognize their association with these malignant diseases. ${ }^{1}$

\section{CASE REPORT}

A 44-year-old Caucasian male presented to our
Dermatology clinic with multiple erythematous-brownish macules and nodules, extensive dyscromia on the lower limbs and an axillary adenopathy (Figure 1). The patient had a previous diagnosis of peripheral $T$ cell lymphoma not-otherwise specified (according to the 2008 WHO classification), established two years before (stage III-B) and he had undergone chemotherapy at that time ( 4 cycles of $\mathrm{CHOP}-$ cyclophosphamide + bydroxydaunorubicin + vincristine + prednisone and then 4 cycles of fludarabine + cyclophos-

Received on 05.08.2011.

Approved by the Advisory Board and accepted for publication on 08.11.2011.

* Study carried out at the University Dermatology Clinic, North Lisbon Hospital Center, Santa Maria Hospital (Clínica Universitária de Dermatologia - Centro Hospitalar Lisboa do Norte - Hospital de Santa Maria - EPE- HSM) - Lisbon, Portugal.

Conflict of interest: None

Financial funding: None

M.D. - Intern at the Dermatovenereology Department. University Dermatology Clinic, North Lisbon Hospital Center, Santa Maria Hospital (Clínica Universitária de Dermatologia - Centro Hospitalar Lisboa do Norte - Hospital de Santa Maria - EPE- HSM) - Lisbon, Portugal.

PhD - Dermatologist. University Dermatology Clinic, North Lisbon Hospital Center, Santa Maria Hospital (Clínica Universitária de Dermatologia - Centro Hospitalar Lisboa do Norte - Hospital de Santa Maria - EPE- HSM) - Lisbon, Portugal.

M.D. - Hematologist. Hematology Service, North Lisbon Hospital Center, Santa Maria Hospital (Centro Hospitalar Lisboa do Norte - Hospital de Santa Maria - EPE- HSM) - Lisbon, Portugal. 


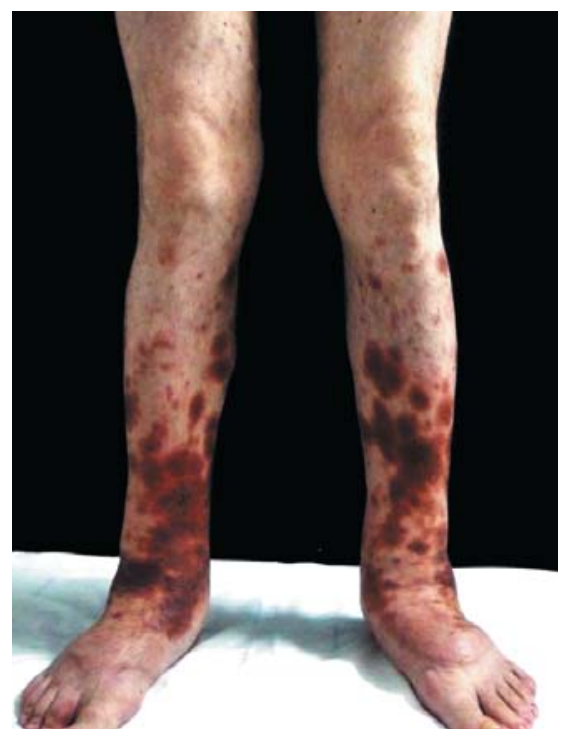

Figure 1: Clinical image: cutaneous infiltration with extensive dyschromia

phamide + mitoxantrone) ${ }^{3}$ He had a complete response, without recurrences.

Skin biopsies revealed the presence of sarcoid granulomas, without necrosis and with a dense inflammatory infiltrate constituted of small/medium lymphoid cells, with irregular nuclei, dispersed chromatin, numerous mitoses, and some epithelioid histiocytes (Figure 2). The immunostaining revealed a $\mathrm{CD} 3+, \mathrm{CD} 20-$ population and a high proliferative index (Ki67 > 50\%) (Figure 3). Molecular analysis demonstrated a monoclonal rearrangement of the Tcell receptor.

The laboratory studies revealed increased b2 microglobulin $(2.69 \mathrm{mg} / \mathrm{L}$, normal range: 0,8-1,8 $\mathrm{mg} / \mathrm{L}$ ) and lactate dehydrogenase within the normal range, with no other anomalies. Microbiology studies and serologies for human immunodeficiency virus 1 and 2, hepatitis B virus, hepatitis $\mathrm{C}$ virus, human T-cell lymphotropic virus type 1 and syphilis were also negative. The cutaneous granulomas revealed the recurrence of peripheral T-cell lymphoma (recurrence stage: $\mathrm{IV}_{\mathrm{D}^{-\mathrm{A}}}$ ) and a new chemotherapy scheme was started (gemcitabine + oxaliplatin) for three months, without response. Immunostaining for CD25 was performed on the request of Hematology, in order to introduce denileukin diftitox, which is specified on advanced/terminal stages of $\mathrm{T}$-cell lymphomas, when more than $25 \%$ of the tumor express CD25. The patient refused further treatment and abandoned the clinic for a year. When he returned, dissemination of skin lesions was observed and alemtuzumab was started. The patient presented an initial response to the first two cycles, but then he developed a cytomegalovirus infection and was admitted to our Hematology department for two weeks. One month later he was readmitted for febrile neutropenia and died two days later, without isolation of any infectious agent.

\section{DISCUSSION}

Granulomas can occur in primary or secondary cutaneous lymphomas and two different patterns of skin granulomatous infiltrates in lymphoma have been described: cutaneous granulomas constituting a non-specific manifestation of the underlying lymphoma, interpreted as an immunologic hypersensitivity reaction, and granulomatous infiltrates admixed with neoplastic cells. ${ }^{1,2,4-6,7}$

Histologically, non-necrotizing epithelioid granuloma (sarcoid-like) formation is the most frequently reported "non-specific" pattern, previously referred to as "sarcoidosis-lymphoma syndrome". 4,7

In the past, granulomas were considered as a good prognostic indicator, since some authors sugges-
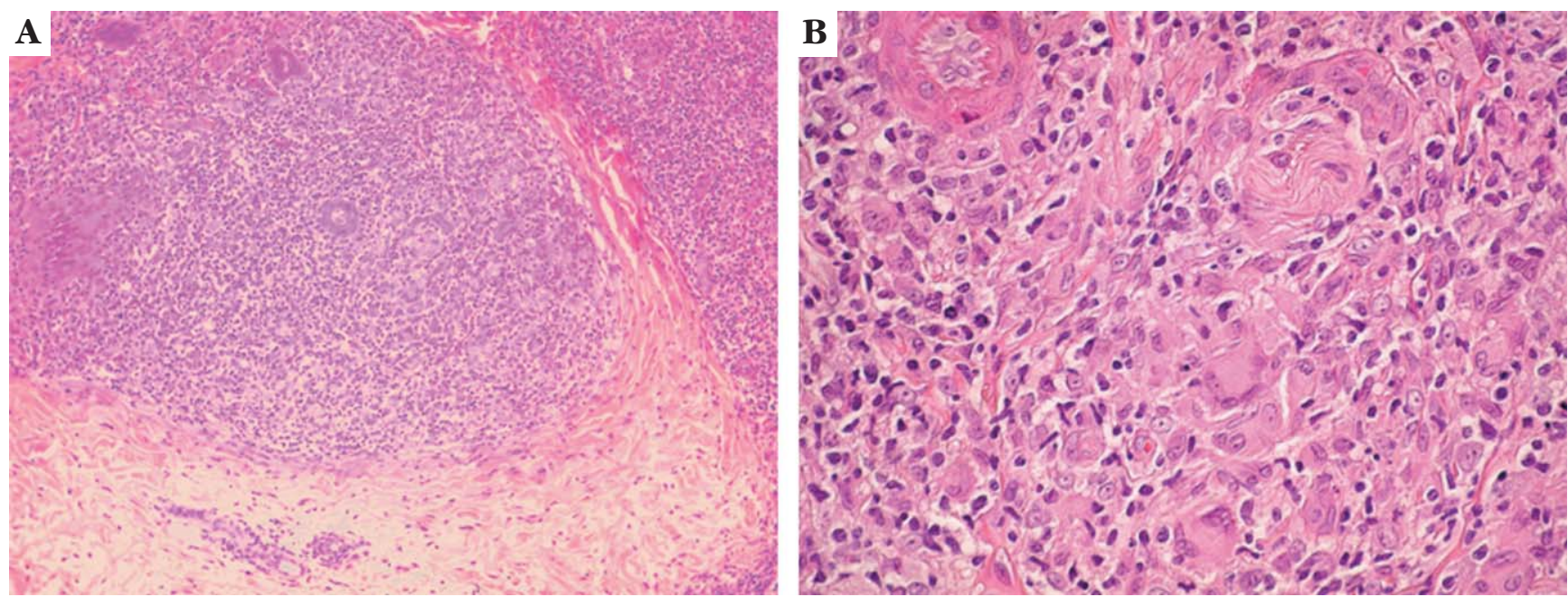

FIGURE 2: Histopathologic examination revealed: dermal granulomas of the sarcoid type (with some epithelioid histiocytes) with small/ medium atypical lymphoid cells. HE x100 (A) and x400 (B) 


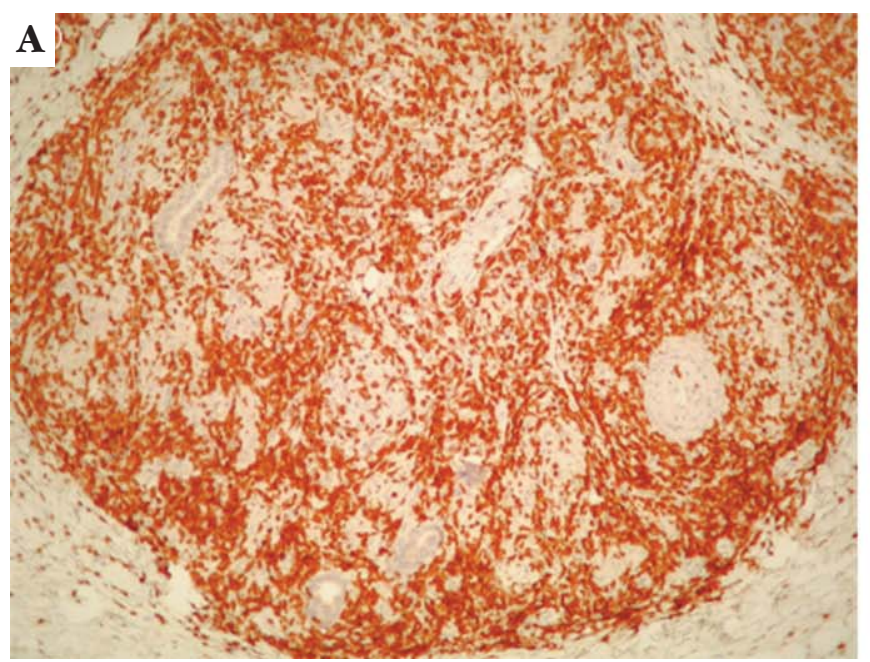

Figure 3: Immunostaining: high expression of $\mathrm{CD}$

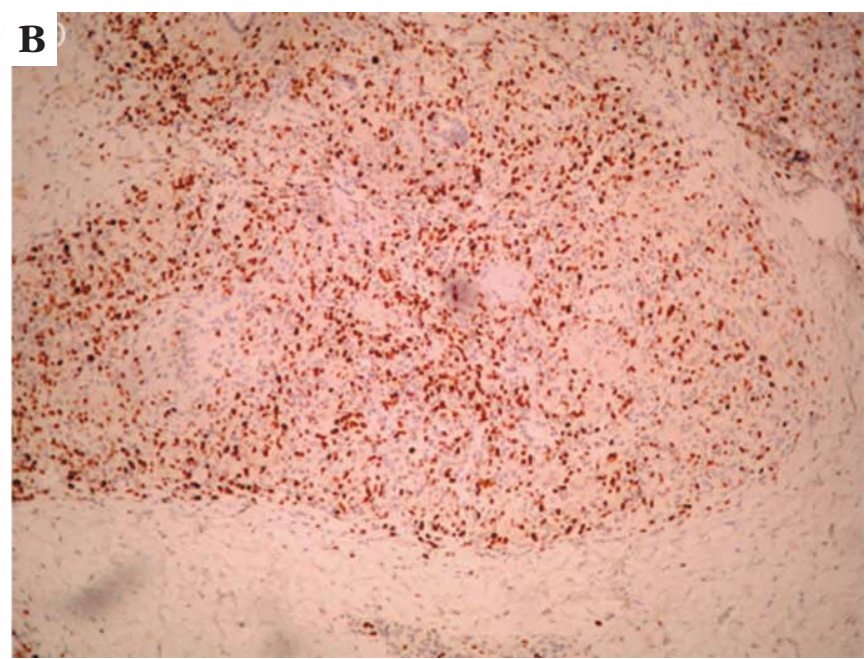

(A) and high proliferative index (Ki67 > 50\%) (B) ted that they were a host-protective response against the malignant lymphoma. ${ }^{4,5}$ However, prognosis is poor in cases of secondary involvement of the skin by nodal lymphoma, and other parameters, such as clinical features, cytological aspects and immunohistochemical markers may influence the outcome. ${ }^{8}$ At present, there is no evidence to support any relationship between granuloma formation and prognosis of the associated systemic lymphoma. ${ }^{4,5}$

Peripheral T-cell lymphomas, such as the one described above, are a heterogeneous group of T-cell malignancies characterized by an aggressive behavior and deceptive prognosis, with less than $30 \%$ of patients being cured by anthracycline-containing therapies (such as CHOP or CHOP-like regimens). 9,10

\section{REFERENCES}

1. Gallardo F, Garcia-Muret MP, Servitje 0, Estrach T, Bielsa I, Salar A, et al. Cutaneous lymphomas showing prominent granulomatous component: clinicopathological features in a series of 16 cases. J Eur Acad Dermatol Venereol. 2009;23:639-47.

2. Randle HW, Banks PM, Winkelmann RK. Cutaneous granulomas in malignant lymphoma. Arch Dermatol. 1980;116:441-3.

3. Zerbini MCN, Soares FA, Velloso EDRP, Chaufaille MLL, Paes RP. World Health Organization Classification of tumors of hematopoietic and lymphoid tissues, 4th edition, 2008 - major changes from the 3rd edition, 2001. Assoc Med Bras. 2011;57:66-73.

4. Cerroni, L. Cutaneous granulomas and malignant lymphomas. Dermatology. 2003;206:78-80.

5. Rongioletti F, Cerroni L, Massone C, Basso M, Ciambellotti A, Rebora A. Different histologic patterns of cutaneous granulomas in systemic lymphoma. J Am Acad Dermatol. 2004;51:600-5.

6. Pujol RM, Gallardo F, Servitje 0, Martí RM, Bordes R, García-Muret MP, et al. Peripheral T-cell lymphoma with secondary epithelioid granulomatous cutaneous involvement: a clinicopathologic study of four cases. J Dermatol. 2005;32:541-8.

7. Diette KM, Caro WA, Roenigk HH Jr. Malignant lymphoma presenting with cutaneous granulomas. J Am Acad Dermatol. 1984;10:896-902.
Therefore, other strategies such as high-dose chemotherapy, autografting and biologically targeted therapies have been explored, but without any large series being published in literature. The CD52 antigen seems a suitable target for chemo-immunotherapy programs, given the availability of the anti-CD52, alemtuzumab, which has recently been increasingly considered in therapeutic programs for T-cell disorders, although with an important risk of potential life-threatening opportunistic infections, as described in our case.

Dermatologists must be familiar with the different presentations of systemic or cutaneous primary lymphomas. These diseases should be considered in the differential diagnosis of skin granulomas, after ruling out the more common infectious causes.

8. Marzano AV, Vanotti M, Boneschi V, Gianelli U, Alessi E. Nodal Peripheral T-cell Lymphoma with secondary granulomatous cutaneous involvement. Acta Derm Venereol. 2003; 84: 325-7.

9. Sanches Jr JA, Moricz CZM, Festa Neto C. Processos linfoproliferativos da pele: parte 2 - linfomas cutâneos de células T e de células NK. An Bras Dermatol. 2006; 81:7-25.

10. Gallamini A, Zaja F, Patti C, Billo A, Specchis MR, Tucci A, et al. Alemtuzumab (Campath-1H) and CHOP chemotherapy as first-line treatment of peripheral T-cell Iymphoma: results of a GITIL(Grupo Italiano Terapie Innovative nei Linfomi) prospective multicenter trial. Blood. 2007;110:2316-23.

\author{
MAILING ADDRESS: \\ Ana Rita Travassos \\ Avenida Professor Egas Moniz \\ 1649-028 Lisboa, Portugal \\ E-mail: ritatravassos@gmail.com
}

How to cite this article: Travassos AR, Borges-Costa J, Raposo J, Almeida LS, Filipe P. Recurrence of peripheral T-cell lymphoma as granulomas in the lower limbs. An Bras Dermatol. 2012;87(5):772-4. 